\title{
Vertical Market Integration for Beef Prices Using Vector Error Correction Model (VECM) In Indonesia
}

\author{
Rudi Wibowo ${ }^{\text {a }, ~ A h m a d ~ Z a i n u d d i n, ~}{ }^{\mathrm{a},}$, Rena Yunita Rahman ${ }^{\mathrm{a}}$, Intan Kartika Setyawatia, \\ Illia Seldon Magfiroh ${ }^{\mathrm{a}}$, Indah Ibanah ${ }^{\mathrm{a}}$ \\ ${ }^{a}$ Department of Agribusiness, Faculty of Agriculture, University of Jember, Jl. Kalimantan 37, Jember, Indonesia \\ Corresponding author: ${ }^{*}$ zainuddin91.faperta@unej.ac.id,
}

\begin{abstract}
Normatively, price changes that occur in the consumer market will be passed on to the producer's market. The price change is not necessarily enjoyed by beef cattle farmers in Indonesia. The purpose of this research was to examine whether there is a vertical market integration of beef among consumer and producer market in Indonesia. The examination of this issue was done through the Vector Error Correction Model (VECM). The data used in this study were secondary. This study used monthly price data of beef $(\mathrm{Rp} / \mathrm{kg})$ in Indonesia, consisting of 96 observations from January 2011 to December 2018. This study reveals that there is a long-term relationship among the consumer market and producer market in Indonesia. The short-run was also found that vertical beef market integration in Indonesia is only one direction, from consumers to producers. This finding represents that the beef market is vertically integrated, but the integration is not perfect. Imperfect integration of beef marketing in Indonesia signifies that the beef market in Indonesia is inefficient both in the short and long term. This study recommends the government formulate policies that provide infrastructure to avoid market exploitation and asymmetry information from the consumer market to the producer market. Besides, the government needs a price brand policy, where the government sets a reasonable price disparity between prices at the farm level and prices at the consumer level.
\end{abstract}

Keywords - Co-integration; efficiency; cattle farmers; VECM.

Manuscript received 24 Aug. 2019; revised 6 Nov. 2020; accepted 5 Jan. 2021. Date of publication 30 Jun. 2021. IJASEIT is licensed under a Creative Commons Attribution-Share Alike 4.0 International License.

\section{INTRODUCTION}

Beef is one of the most common livestock commodities, which are consumed by the people of Indonesia. The economic value of beef is quite high among other animal protein sources. Even in the past five years, the data explain that domestic beef production tends to increase. However, the production capacity is not enough to reach Indonesians' beef consumption, which also increases significantly [1].

The efforts to increase the productivity for raising the local beef availability is not easy due to the upsurge beef consumption every year. On the contrary, the rise of production of local is not as significant as that of public consumption. This is a big problem in achieving the target of the beef Self-Sufficiency Program in Indonesia. The achievement of the Beef Self-Sufficiency Program in Indonesia still faces several obstacles. The Indonesian beef market is concentrated in East Java and West Nusa Tenggara [2]. Meanwhile, consumer areas are concentrated in West Java and Jakarta. This difference causes the effects of beef price fluctuations in the consumer market, which is not equal to fluctuations in the producer market.

The development of beef consumer prices in Indonesia during the 2015-2018 period has shown a trend of increase, yet, beef producer prices tend to be stable. This causes the beef marketing margin in Indonesia to be higher. The high marketing margin occurs because of low producer price responds the price changes in the consumer market. As a result, beef marketing margins in Indonesia increased. This occurred because of the low producer's price response to price changes in the consumer market (Table 1).

Normatively, price changes that occur in the consumer market will be passed on to the producer market. In fact, the price change is not necessarily enjoyed by beef cattle farmers in Indonesia. However, changes in consumer prices tend to be enjoyed by the middleman. As a result, there has been asymmetrical information about prices in which changes in prices at the consumer level will be directly transmitted to the producer market and vice versa. This has implications for the number of marketing margins. 
The availability of market information, especially price, is needed to prevent market information asymmetry so that price changes can be immediately responded by market participants, and decision making can be fast and appropriate [3]. It shows that integration has occurred among the markets, or one market is well integrated to the others.
In an integrated market, the prices of different markets have a positive relationship as a reflection of the smooth flow of market information [4]. An integrated market will be achieved if there are similar, adequate market information, fast distribution to other markets, and the positive relationship between prices in different markets [5].

TABLE I

DEVELOPMENT OF PRODUCER PRICES AND CONSUMER PRICES FOR BEEF IN INDONESIA 2015-2018

\begin{tabular}{|c|c|c|c|c|c|c|c|c|c|c|c|c|}
\hline \multirow[b]{3}{*}{ Year } & \multicolumn{12}{|c|}{ Month } \\
\hline & Jan & Feb & Mar & Apr & May & Jun & Jul & Aug & Sep & Oct & Nov & Dec \\
\hline & \multicolumn{12}{|c|}{ Consumer Price $(\mathrm{Rp} / \mathrm{kg})$} \\
\hline 2015 & 98761 & 98502 & 98394 & 98759 & 98756 & 100460 & 104361 & 105385 & 105571 & 104772 & 104772 & 104696 \\
\hline 2016 & 105166 & 105825 & 106281 & 106241 & 106390 & 109718 & 110611 & 110147 & 111181 & 109988 & 109378 & 109419 \\
\hline 2017 & 110116 & 110917 & 110668 & 110475 & 110730 & 112549 & 112021 & 111234 & 111060 & 111037 & 111520 & 111162 \\
\hline \multirow[t]{2}{*}{2018} & 111713 & 111153 & 111289 & 111069 & 110759 & 112016 & 110689 & 110474 & 110416 & 109919 & 109298 & 109408 \\
\hline & \multicolumn{12}{|c|}{ Producer Price $(\mathrm{Rp} / \mathrm{kg})$} \\
\hline 2015 & 41389.1 & 41566.2 & 41663.9 & 41744.4 & 41862.8 & 42464 & 42910.3 & 43366.3 & 44172.3 & 43589.7 & 43454.1 & 43463.3 \\
\hline 2016 & 46040.2 & 46069.4 & 46097.6 & 46125.6 & 46229.6 & 46734.2 & 47078.9 & 47648.8 & 48505 & 47905.5 & 47688.4 & 47757.9 \\
\hline 2017 & 48712.9 & 48786.3 & 48788 & 48752.5 & 48919.3 & 49383.9 & 49526.3 & 50238.4 & 50004.1 & 49845.7 & 49815.5 & 50048.6 \\
\hline 2018 & 52843.6 & 52910.1 & 53014 & 53153.4 & 53648.3 & 54367.5 & 54795.7 & 55880.1 & 55153.4 & 54860.7 & 54774 & 54917.2 \\
\hline & \multicolumn{12}{|c|}{ Price Margin (Rp/kg) } \\
\hline 2015 & 57371.9 & 56935.7 & 56730.1 & 57014.6 & 56893.2 & 57996 & 61450.7 & 62018.7 & 61398.7 & 61182.3 & 61317.9 & 61232.7 \\
\hline 2016 & 59125.8 & 59755.5 & 60183.4 & 60115.4 & 60160.4 & 62983.8 & 63532.1 & 62498.2 & 62676 & 62082.5 & 61689.6 & 61661.1 \\
\hline 2017 & 61403.1 & 62130.7 & 61880 & 61722.5 & 61810.7 & 63165.1 & 62494.7 & 60995.6 & 61055.9 & 61191.3 & 61704.5 & 61113.4 \\
\hline 2018 & 58869.3 & 58242.9 & 58275 & 57915.6 & 57110.7 & 57648.5 & 55893.3 & 54593.9 & 55262.6 & 55058.3 & 54524 & 54490.8 \\
\hline
\end{tabular}

Source: [6]-[13]

Research on the integration and transmission of beef prices has been conducted in Indonesia. Research by Rembang et al. [14], Dong et al. [15], Suharno [16], Zainuddin et al. (2015)[17], Fossati et al. (2007) [18], Setiaji et al. [19], Agus and Widi [20] examined the integration of markets and the transmission of spatial prices in the domestic and international markets, as well as marketing and supply chains of beef in Indonesia. The results of the studies showed that the beef market in Indonesia indicated that there is not any perfect integration and transmission of prices. Furthermore, the novelty of this study is to analyze the vertical integration of beef markets between consumer and producer markets in the short and long term. This study used a Vector Error Correction Model (VECM). Another difference is that this study also analyzed the response of cattle farmers to price changes at the consumer level. Based on the background, the aim of this study is to analyze beef market integration vertically between the consumer and producer markets in Indonesia.

\section{MAterials AND Method}

\section{A. Research Data}

The data used in this study were secondary data. This study used monthly price data of beef $(\mathrm{Rp} / \mathrm{kg})$ in Indonesia, consisting of 96 observations from January 2011 to December 2018. There are two groups of data representing the level of markets, namely producer price and consumer price. Those data were collected from the website including www.bps.go.id, and www.pertanian.go.id.

\section{B. Analysis Method}

The analysis of beef market integration at the producer and consumer level in this study used the VAR (Vector Autoregression) / VECM (Vector Error Correction Model) model. The VAR (Vector Autoregressive)/VECM (Vector Error Correction Model). The models were used to analyze the interdependence of beef prices at the producer and consumer levels.

The VAR/VECM model is a linear function of price variables consisting of constants and the lag value of the variable itself and other variables in the system. Thus, the explanatory variables in the VAR / VECM Model include lag values of all dependent variables in the system. The VAR / VECM model has the assumption that all dependent variables are stationary, and all errors are white noise, i.e., they have zero mean, constant variance, and independent. Nonstationary independent variables will produce spurious regression. Non-stationary independent variables often show an imbalanced relationship in the short term, but there is a tendency for a long-term balance relationship. The model used to work with non-stationary data is the VEC (Vector Error Correction) model, where this model will gradually correct the imbalance of the deviation through short-term partial adjustments [21]-[23]. The VAR model of beef market integration at the producer and consumer level is as follows:

$$
\begin{gathered}
\mathrm{Y}_{\mathrm{t}}=\alpha_{1}+\delta_{1 \mathrm{t}}+\sum_{\mathrm{i}=1}^{\mathrm{n}} \delta_{11}(\mathrm{i}) \mathrm{Y}_{\mathrm{t}-\mathrm{i}}+\sum_{\mathrm{i}=1}^{\mathrm{n}} \delta_{12}(\mathrm{i}) \mathrm{Z}_{\mathrm{t}-\mathrm{i}}+\varepsilon_{\mathrm{yt}} \\
\mathrm{Z}_{\mathrm{t}}=\alpha_{2}+\delta_{2 \mathrm{t}}+\sum_{\mathrm{i}=1}^{\mathrm{n}} \delta(\mathrm{i}) \mathrm{Y}_{\mathrm{t}-\mathrm{i}}+\sum_{\mathrm{i}=1}^{\mathrm{n}} \delta_{22}(\mathrm{i}) \mathrm{Z}_{\mathrm{t}-\mathrm{i}}+\varepsilon_{\mathrm{zt}}
\end{gathered}
$$

$Z_{t}$ is the $n x 1$ vector of beef prices at the consumer level in a first-order, generally denoted as I (1); $Y_{t}$ is the price of beef at the producer level, and $\varepsilon t$ is $n x 1$ of the innovation vector [24]. In this research, there are 2 variable prices (beef prices at the consumer level and beef prices at the producer level). If these variables are transformed into a vector, it can be seen in the formulation below [18]: 


$$
\left[\begin{array}{l}
Y_{t} \\
Z_{t}
\end{array}\right]=\left[\begin{array}{l}
\beta_{1} \\
\beta_{2}
\end{array}\right]+\left[\begin{array}{ll}
\beta_{11} & \beta_{12} \\
\beta_{21} & \beta_{22}
\end{array}\right]\left[\begin{array}{l}
Z_{t-1} \\
Y_{\mathrm{t}-1}
\end{array}\right]+\left[\begin{array}{l}
\varepsilon_{1 t} \\
\varepsilon_{2 t}
\end{array}\right]
$$

In which:

$\mathrm{Y}_{\mathrm{t}} \quad=$ beef price at the consumer level $(\mathrm{Rp} / \mathrm{kg})$

$\mathrm{Z}_{\mathrm{t}} \quad=$ beef price at the producer level $(\mathrm{Rp} / \mathrm{kg})$

$\alpha_{\mathrm{i}} \quad=$ parameters to estimate

The specifications of the VECM model of beef market integration at the producer and consumer levels are as follows:

$$
\begin{aligned}
& \Delta \mathrm{Y}_{\mathrm{t}}=\phi_{1}+\delta_{1 t}+\lambda_{\mathrm{y}} e_{t-1}+\sum_{\mathrm{i}=1}^{\mathrm{n}} \gamma_{11}(\mathrm{i}) \Delta \mathrm{Y}_{\mathrm{t}-\mathrm{i}}+\sum_{\mathrm{i}=1}^{\mathrm{n}} \gamma_{12}(\mathrm{i}) \Delta \mathrm{Z}_{\mathrm{t}-\mathrm{i}}+\varepsilon_{\mathrm{yt}} \\
& \Delta \mathrm{Z}_{\mathrm{t}}=\phi_{2}+\delta_{1 t}+\lambda_{\mathrm{z}} e_{t-1}+\sum_{\mathrm{i}=1}^{\mathrm{n}} \gamma_{21}(\mathrm{i}) \Delta \mathrm{Y}_{\mathrm{t}-\mathrm{i}}+\sum_{\mathrm{i}=1}^{\mathrm{n}} \gamma_{22}(\mathrm{i}) \Delta \mathrm{Z}_{\mathrm{t}-\mathrm{i}}+\varepsilon_{\mathrm{zt}}
\end{aligned}
$$

In which:

$$
\begin{array}{ll}
\mathrm{Y}_{\mathrm{t}} & =\text { vector that contains the variables analyzed in the } \\
& \text { study (beef price at producer level }(\mathrm{Rp} / \mathrm{kg}) \\
\mathrm{Z}_{\mathrm{t}} & =\text { beef price at the consumer level }(\mathrm{Rp} / \mathrm{kg}) \\
\varphi_{\mathrm{x}} & =\text { vector } \text { intercept } \\
\delta_{2 \mathrm{i}} & =\text { regression coefficient vector } \\
\mathrm{t} & =\text { time trend } \\
\gamma_{\mathrm{i}} & =\alpha \times \beta^{\prime} \text { in which b' contains a long-term } \\
& \text { cointegration equation } \\
\mathrm{Y}_{\mathrm{t}-\mathrm{i}} ; \mathrm{Z}_{\mathrm{t}-\mathrm{i}} & =\text { variable } \text { in-level } \\
\lambda_{\mathrm{x}} & =\text { Regression coefficient matrix that shows short- } \\
& \text { term integration } \\
\varepsilon_{t} & =\text { error term }
\end{array}
$$

The stages of data processing using the VAR/VECM model are:

a) Stationary Test or Unit Root Test

b) Determining Optimum Lag

c) Cointegration Test (Johansen Cointegration Test)

d) Estimation of the VAR / VECM Model

The software used in this study is Microsoft Excel 2016 to create data tabulations and EViews 7 to process VAR/VECM data models.

\section{RESULT AND DISCUSSION}

Normally, beef prices at the consumer level affect each other on changes in beef prices at the producer level; if consumer prices increase, producer prices will increase and vice versa. This happens because of market integration in which changes in prices at the consumer level will be transmitted to producers and vice versa. However, conditions in the field are different; beef consumer prices have a different level of change from that of price changes at the producer level. This shows that there is no perfect transmission of prices from the consumer market to the producer market; thus, price changes at the consumer level may not necessarily be enjoyed by producers.

Figure 1 shows that beef prices at the producer level from 2011 to 2018 were relatively stable, while beef prices at the consumer level slightly fluctuated with an increasing trend. The slight differences in price fluctuations at the consumer and producer levels indicate asymmetric information from the consumer market to the producer market.
This result is in contrast with Bakucs and Ferto [25] research, which states that the beef market in Hungary is symmetric. Marketing conditions in Hungary shows that price information is well channeled from consumers to producers.

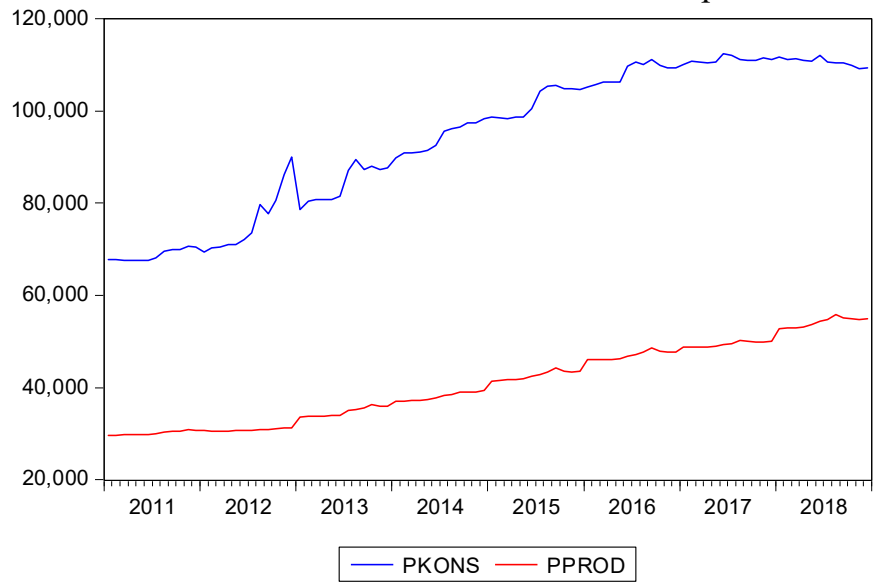

Fig. 1 Beef price movements at the producer and consumer level 2011-2018 Source: [6]-[13], (Processed)

In the Indonesian market, price information from the consumer market is not necessarily transmitted to the producer market. Two things can cause the asymmetric information: first, farmers are not responsive to price changes. Most of the breeders in Indonesia (90 percent) are smallholder cattle farmers who only have 1-3 cattle, and the livestock business is still subsistence where farmers will sell their livestock when they need money. These properties cause farmers to be irresponsive about price changes.

Second, there is an imperfect price transmission from intermediary traders. In addition to the nature of cattle farmers who do not respond to prices, the causes of differences in beef price fluctuations at the producer and consumer levels are considered to occur as asymmetric prices. Price information from the consumer level is not well transmitted to the level of beef producers; consequently, intermediary traders enjoy the benefits of price changes more. This shows that the bargaining position of cattle farmers is weak and that the cattle farmers are more a price taker.

Weak bargaining position is caused by the condition where beef cattle farmers sell their castles when they need money. As a result, farmers tend to accept whatever the price offered by the traders. In the marketing chain of cattle, farmers have the weakest position because it is assumed that farmers generally do not have access to market information that can be used as a basis for bargaining.

Figure 1 also implies a very wide gap between beef producer prices and beef consumer prices (high marketing margin gap). It is common knowledge that beef marketing is a very long marketing chain starting from cattle farmers, belantik (cattle traders), slaughterhouses, butchers, and retailers [19]. Strangely the livestock sales system, as described above, has been going on for a long time without any change, and it seems as though there is nothing wrong with the chain link. Whereas the financing and profits of each actor in the marketing chain will be a reduction to the acquisition of farmers as producers. In addition, the determination of the selling price of livestock at the farmer level is done by an estimated system, which, of course, tends 
to harm the cattle farmers. This is certainly very detrimental to farmers as producers of beef cattle.

The relatively high margin difference shows that marketing beef from producers to consumers is inefficient. The inefficient marketing of beef is caused by high transportation costs and many market players from producers to consumers. This is supported by the statement of Ilham [26]; Zinovchuk and Rud [27]; Abdulai [28]; Setiaji et al. [19] which proved that the pattern of trade system channels in beef cattle centers relatively involves cattle traders while in the consumption center areas, there are more cattle traders resulting in the increase of marketing as the marketing actors also increase. Many market players in the production and consumption centers cause a high marketing margin, high marketing costs (transportation costs), and high margin difference between production and consumption prices. Therefore, it is necessary to regulate beef cattle trading through improving transportation facilities to reduce the marketing margins of beef.

Another factor was causing the high margin differences in the existence of market power by intermediary traders. The market structure greatly influences the size of the profit margins that can be determined by economic agents in the meat marketing chain [29], [19]. Most beef marketing is more controlled by intermediary traders; therefore, producers and consumers do not get more margins. In the case of beef, the subsistence nature of cattle farmers has no bargaining position to set prices, which causes farmers to be forced to become price takers [30]. Conversely, at the level of traders (both inaugurated and large traders), the smaller number of traders will tend to have the power to influence prices. Even large traders form cartels to make the deals in the market.

The implications of the market structure described above cause farmers and consumers to be in a weak bargaining position, and in contrast, intermediary traders and large traders are in a dominant position. This is reinforced by the research of Antara and Sumarniash [31], which shows that the marketing margins in beef marketing are high not only because of the national beef deficit causing prices to rise, but also cartel among fellow beef entrepreneurs. Even the government, through the Business Competition Supervisory Commission (KPPU), has imposed fines on 32 feedlots. The existence of a strong bargaining power causes them to be able to control the process of transmitting cattle prices from cattle farmers to consumers.

1) Stationary Test: Table 2 shows that the variables of beef price in the level of producers and consumers have done Stationary tests at the error level of $1 \%, 5 \%$, and $10 \%$ using the criteria of intercept and trend.

TABLE II

Stationary Test on BeEF Prices of CONSUMERs AND Producers

\begin{tabular}{|c|c|c|c|c|c|c|}
\hline \multirow{3}{*}{ Variable } & \multirow{3}{*}{ Differenced } & \multicolumn{4}{|c|}{ Intercept Without Trend } & \multirow{3}{*}{ Conclusion } \\
\hline & & \multirow{2}{*}{$\begin{array}{c}\text { ADF test } \\
\text { statistic } \\
\text { Value }\end{array}$} & \multicolumn{3}{|c|}{$\begin{array}{c}\text { McKinnon Critical } \\
\text { Value }\end{array}$} & \\
\hline & & & $1 \%$ & $5 \%$ & $10 \%$ & \\
\hline Consumer & $\mathrm{I}(0)$ & -1.32 & -4.06 & -3.46 & -3.16 & Not stationary \\
\hline Prices & $\mathrm{I}(1)$ & -8.63 & -4.06 & -3.46 & -3.16 & Stationary \\
\hline Producer & $\mathrm{I}(0)$ & -2.14 & -4.07 & -3.46 & -3.16 & Not stationary \\
\hline Prices & $\mathrm{I}(1)$ & -5.37 & -4.06 & -3.46 & -3.16 & Stationary \\
\hline
\end{tabular}

The results of the analysis imply that the price of beef at the producer and consumer level is not stationary at the level.
This indicates that the value of the ADF statistic at a level greater than the critical value of McKinnon, and the ADF value on the physical difference shows the opposite value.

2) Determination of Optimal Lag: The lag length of a VAR / VECM model is known based on the AIC (Akaike Information Criteria) criteria. The optimal lag length for the VAR / VECM model in this study is lag 3 (Table 3).

TABLE III

Criteria FOR OPTIMUM LAG IN BEEF PRICES FOR PRODUCERS AND CONSUMERS IN INDONESIA

\begin{tabular}{cccll}
\hline Lag & LR & AIC & SC & HQ \\
\hline 0 & NA & 68.311 & 68.473 & 68.371 \\
1 & 251.613 & 62.586 & $63.397^{*}$ & $62.887^{*}$ \\
2 & 17.122 & 62.824 & 64.284 & 63.366 \\
3 & $32.956^{*}$ & $62.488^{*}$ & 64.597 & 63.270 \\
4 & 12.222 & 62.763 & 65.520 & 63.786 \\
\hline \multicolumn{5}{l}{ Source: [6]-[13], (Processed) }
\end{tabular}

Source: [6]-[13], (Processed)

3) Cointegration Test: This co-integration test is used to determine the occurrence of integration in the same degree between beef prices at the consumer and producer level, and therefore, it is said to be cointegrated. Table 4 shows that there is a co-integration relationship (long-term integration) between prices at the producer and consumer level of beef in Indonesia. This is indicated by the value of the trace statistic and the maximum eigenvalue, which rejects $\mathrm{H} 0$ at a significance level of $5 \%$. This value indicates that there is a cointegrated equation that explains the long-term integration relationship between producer prices and beef consumers.

TABLE IV

JOHANSEN COINTEGRATION TESTING

\begin{tabular}{crlrr}
\hline $\begin{array}{c}\text { Number of } \\
\text { Cointegration } \\
\text { Equations }\end{array}$ & $\begin{array}{c}\text { Trace } \\
\text { Statistic }\end{array}$ & $\begin{array}{l}\text { Critical } \\
\text { Value } \\
\mathbf{5 \%}\end{array}$ & $\begin{array}{c}\text { Mx- } \\
\text { Eigen } \\
\text { Statistic }\end{array}$ & $\begin{array}{c}\text { Critical } \\
\text { Value 5\% }\end{array}$ \\
\hline None* & 18.772 & 13.398 & 17.380 & 13.148 \\
At most 1* & 21.392 & 13.842 & 21.392 & 13.841 \\
At most 2 & 7.739 & 15.495 & 4.688 & 14.265 \\
\hline Source: [6]-[13] (Processed) & & &
\end{tabular}

4) Granger Causality Test: The probability value generated in the granger causality test in Table 5 shows that beef consumer prices affect producer prices, which are an accepted hypothesis.

TABLE V

GRANGER CAUSALITY TEST RESUlTS

\begin{tabular}{|c|c|c|c|}
\hline Hypothesis: & Obs & F-Statistic & Probability \\
\hline $\begin{array}{l}\text { Producer Prices affect } \\
\text { Consumer Prices }\end{array}$ & 94 & 0.153 & 0.8580 \\
\hline $\begin{array}{l}\text { Consumer Prices } \\
\text { affect Producer Prices }\end{array}$ & 94 & 4,075 & 0.0203 \\
\hline
\end{tabular}

This is because the resulting probability value is less than the $5 \%$ significance level, concluding that the price of beef at the producer level follows price movements at the consumer level. This means that the producer beef market is a follower market, while the consumer market is a reference market. In addition, prices at the producer level cannot affect prices at the consumer level. The statement implies that the consumer market acts as a reference market and producer markets as follower markets.

Granger causality test results show that consumer prices affect prices at the producer level, which means that the 
relationship between markets is one-way or hierarchical. If prices at the consumer level move first, then prices at the producer level follow. The direction of the movement indicates that the price of beef commodities is determined by consumer prices. If there is a change in prices at the consumer level, it will immediately be responded by the price at the producer level.

5) VECM Estimation Results. In this research, it is known that there is a co-integration in the integration model of the beef producer and consumer market in Indonesia. The existence of co-integration in the system shows that there is a long-term structural relationship between the market at the beef producer center and the beef consumer market. The longterm relationship between market prices of producers and beef consumers can be seen in Table 6 .

TABLE VI

LONG-TERM CO-INTEGRATION BETWEEN PRODUCER AND CONSUMER MARKETS IN INDONESIA

\begin{tabular}{llcl}
\hline Co-integration & \multicolumn{3}{c}{ Beef Price Variable } \\
\cline { 2 - 4 } Equation & P_Prod & P_Kons & C \\
\hline Cointegration 1 & 1.000000 & 0.534 & -31982.02 \\
& \multicolumn{3}{c}{$(0.239)$} \\
\\
\end{tabular}

Source: [6]-[13], (Processed)

Note: The number in [ ] is a statistical value $* * *=$ real at the $1 \%$ level $* *=$ real at the $5 \%$ level and $*=$ real at the $10 \%$ level. $\mathrm{T}$ table value: $\mathrm{t}(\alpha=1 \%)=$ $2.326, \mathrm{t}(\alpha=5 \%)=1.960, \mathrm{t}(\alpha=10 \%)=1.645$

Table 6 shows that the consumer-level beef market has a significant influence on the beef market at the producer level of $-0,534$. The co-integration estimation results are negative, which means that every 1 percent increase in consumer prices will increase producer prices by 0.534 percent eventually. The beef consumer market is a reference market for beef producers' markets. Therefore, if there is a change in prices at the consumer level, it will cause changes in prices at the producer level. Normatively, price increases at the consumer level can be a positive stimulus to price increases received by producers after being reduced by transfer costs. However, sometimes inaccuracies and speed of information and the proximity of the consumer market location to producer markets can cause the relationship to be unidirectional and the magnitude of prices transmitted to be different. This can be caused by the presence of market power in the beef trade. The cause of price asymmetry in the integration of large markets is the presence of market power that affects the size of the profit margins that can be determined by economic agents in the marketing chain [32]. The existence of such market power can cause prices accepted by the consumers are not transmitted to beef producers. Table 7 also shows that in the beef consumer market, there is a significant error correction term of 0.024 .

This value indicates that in the consumer market, there is an adjustment from the short-term equation to the long-term equation of 0.024 , or every month the error is corrected by 0.024 towards its long-term balance.

The effect of each variable of consumer and producer prices in the short run shows that the price movement of beef at the producer level is significantly affected by beef prices at the consumer level (both in the t- 1 or $t-2$ periods). The coefficient of influence is 0.088 at $\mathrm{t}-1$ and 0.165 at $\mathrm{t}-2$. This indicates that the previous price on the consumer market is used as a reference in determining or forming beef cattle prices at the producer level. If there is an increase of $1 \%$ in the price of beef in the consumer market in the previous month, it will be responded positively by the producer market by raising the price of beef cattle by $0.088 \%$ in the current period. This indicates that beef prices are largely determined by prices at the consumer level. If there is a change in price at the consumer level, it will be responded by the producer (price changes from downstream to upstream).

TABLE VII

SHORT-TERM CO-INTEGRATION BETWEEN PRODUCER AND CONSUMER MARKETS IN INDONESIA

\begin{tabular}{ccc}
\hline Error Correction: & D(P_Kons) & D(P_Prod) \\
\hline CointEq1 & 0.024003 & 0.029393 \\
& $(0.03880)$ & $(0.01132)$ \\
D(P_Kons $(-1))$ & {$[2.61872]^{* *}$} & {$[0.59599]$} \\
& 0.041314 & -0.005452 \\
D(P_Kons(-2)) & $(0.10795)$ & $(0.03151)$ \\
& {$[1.88271]^{*}$} & {$[-0.17306]$} \\
D(P_Prod(-1)) & -0.196818 & 0.034786 \\
& {$[0.10743)$} & $(0.03135)$ \\
D(P_Prod(-2)) & 0.145614 & {$[0.10948]$} \\
& $(0.34764)$ & 0.088980 \\
& {$[0.41887]$} & $(0.10146)$ \\
C & -0.458880 & {$[3.87701]^{* * *}$} \\
& {$[-0.34897)$} & 0.165940 \\
& 642.4518 & $(0.10185)$ \\
& $(251.971)$ & {$[1.62928]^{* *}$} \\
& {$[2.54970]^{* *}$} & 326.1315 \\
& & $(73.5381)$ \\
\end{tabular}

Source: [6]-[13], (Processed)

note: The number in [ ] is statistical value $* * *=$ very real on the $1 \%$ level, $* *=$ real at $5 \%$ level and $*=$ real at the $15 \%$ level.

While beef prices at the consumer level were only influenced by consumer prices in the previous month. Beef's level of consumer prices in the previous month had an effect of 0.041 at a $10 \%$ level of trust. This figure indicates that the formation of beef consumer prices refers to changes in beef prices in the previous period. If an increase in beef prices at the consumer level by $1 \%$ in the previous period, it will increase beef prices at the consumer level by $0.041 \%$ in the current period. This also shows that the beef price trend at the consumer level will continue to increase every period, as seen in the short term.

Beef market integration at the consumer and producer level in Indonesia is only one way in the short and long term, or it can be said that the integration is imperfect. This research is linear with research Abdulai [28]; Atozou et al. [33]; Diakosavvas [34] which states that there was no perfect integration in the beef market because the number of butchers and retailers cause consumer prices to be responded to more quickly by retailers compared to farmers' responses. These results were in contrast with research by Rembang et al. [14]; which shows that there is a perfect integration of the beef market from producers and consumers in Minahasa because prices at consumers and producers influence respectively. Furthermore, the research by Bakucs and Ferto [25]; Boluk and Karaman [35]; Braha et al. [36] also stated that in beef marketing in developing countries, there would be perfect market integration if accompanied by government policies. Imperfect integration of beef marketing in Indonesia shows 
that the beef market in Indonesia is inefficient both in the short and long term.

\section{CONCLUSION}

The purpose of this research was to examine whether there is a vertical market integration of beef among consumer and producer market in Indonesia. The examination of this issue was done through the Vector Error Correction Model (VECM). The Johansen co-integration test shows that there is a long-term relationship among consumer and producer market of beef in Indonesia. Granger causality test results show that consumer prices affect prices at the producer level, which indicates that the relationship between markets is oneway or hierarchical. If prices at the consumer level move first, then prices at the producer level follow.

In addition, Beef market integration at the consumer and producer level in Indonesia is only one way in the short run, or in other words; the integration is imperfect. The beef consumer market is a reference market for beef producers' markets. Therefore, there is a change in prices at the consumer level, which will cause changes in prices at the producer level. Imperfect integration of beef marketing in Indonesia signifies that the beef market in Indonesia is inefficient both in the short and long term. The inefficient marketing of beef is caused by high transportation costs and many marketing institutions, from producers to consumers, which causes a long marketing channel for beef. In addition, the existence of market power from intermediary traders and large traders who can determine the price. Has the implications for the high price disparity between the cattle farmer/producer level and the consumer level.

Based on these finding, this research recommends the government to formulate policies which provide the infrastructure to avoid market exploitation and asymmetry information from the consumer market to producer market. Moreover, the government needs a price brand policy to set a reasonable price disparity between prices at the farm level and prices at the consumer level. To determine a reasonable range, the government needs to pay attention to price levels that are not exploitative for consumers while still providing an ideal margin for intermediary traders.

\section{REFERENCES}

[1] BPS, "Distribusi Perdagangan Komoditas Daging Sapi di Indonesia 2018," 2018.

[2] A. Zainuddin, "Faktor-faktor yang Mempengaruhi Keberhasilan Swasembada Daging Sapi 2014 di Jawa Timur,” Fakultas Pertanian Universitas Jember, Jember, 2013.

[3] IFAD; IMF;, and FAO, "Price Volatility in Food and Agricultural Markets: Policy Responses,” 2011.

[4] M. Ravallion, "Testing Market Integration," Am. J. Agric. Econ., vol. 88, no. 1, pp. 102-109, 1986

[5] G. Baffes, J.; Bruce, "The Transmission of World Commodity Prices to Domestic Markets under Policy Reforms in Developing Countries," J. Econ. Policy Return, vol. 6, no. 3, pp. 159-180, 2003.

[6] BPS, Agricultural Producer Prices Statistic: Animal Husbandry \& Fishery Subsector 2015. Jakarta: BPS, 2016.

[7] BPS, Rural Consumer Price Statistics: Food Groups 2015. Jakarta: BPS, 2016.

[8] BPS, Agricultural Producer Prices Statistic: Animal Husbandry \& Fishery Subsector 2016. Jakarta: BPS, 2017.

[9] BPS, Rural Consumer Price Statistics: Food Groups 2016. Jakarta: BPS, 2017.
[10] BPS, Agricultural Producer Prices Statistic: Animal Husbandry \& Fishery Subsector 2017. Jakarta: BPS, 2018.

[11] BPS, Rural Consumer Price Statistics: Food Groups 2017. Jakarta: BPS, 2018.

[12] BPS, Agricultural Producer Prices Statistic: Animal Husbandry \& Fishery Subsector 2018. Jakarta: BPS, 2019.

[13] BPS, Rural Consumer Price Statistics: Food Groups 2018. Jakarta: BPS, 2019.

[14] V. V. J. Rembang, V.L.H.; Hartono, B.; Utami, H.D.; Panelewen, "The Analysis of Beef Cattle Structural Marketing in North SulawesiIndonesia," Spec. J. Agric. Sci., vol. 2, no. 1, pp. 20-27, 2016.

[15] J. Dong, X.; Waldron, S.; Brown, C.; Zhang, "Price transmission in regional beef markets: Australia, China, and Southeast Asia," Emirates J. Food Agric., vol. 30, no. 2, pp. 99-106, 2018.

[16] S. Suharno, "Spatial Market Integration and Price Transmission of Meat in Indonesia," in 30th International Conference of Agricultural Economists, 2018, pp. 1-24.

[17] R. W. . H. Zainuddin, A.; Asmarantaka, "Integrasi Harga Daging Sapi di Pasar Domestik dan Internasional," Bul. Ilm. Litbang Perdagang., vol. 9, no. 2, pp. 1-12, 2015

[18] C. M. Fossati, S.; Lorenzo, F.; Rodriguez, "Regional and International Market Integration of A Small Open Economy," J. Appl. Econ., vol. 10, no. 1, pp. 77-98, 2007.

[19] H. D. Setiaji, B.; Susila, I.; Wahyudi, "Supply Chain of the Beef Market in Indonesia," Expert J. Bus. Manag., vol. 5, no. 2, pp. 129$135,2017$.

[20] T. S. M. Agus, A.; Widi, "Current situation and the prospect of beef cattle production in Indonesia-A review," Asian Australas. J. Anim. Sci., vol. 31, no. 1, pp. 1-8, 2018.

[21] W. Enders, Applied Econometric Time Series. New York: John Wiley \& Sons, 1995

[22] D. Gujarati, Basics Econometrics, 4th ed. New York: The McGraw Hill Companies, 2004

[23] S. V. C. Acosta, A.; Ihle, R.; Taubadel, "Combining market structure and econometric methods for price transmission analysis," Food Secur., vol. 20, no. 2, pp. 1-11, 2019.

[24] D. Rosadi, Ekonometrika dan Analisis Runtun Waktu Terapan dengan Eviews. Yogyakarta: Penerbit Andi Yogyakarta, 2012.

[25] I. Bakucs, L.Z.; Ferto, "Marketing margins and price transmission on the Hungarian beef market," Food Econ., vol. 3, no. 1, pp. 151-160, 2006.

[26] N. Ilham, "Analisis Ekonomi dan Strategi Pencapaian Swasembada Daging 2010," Bogor, 2006

[27] V. Zinovchuk, V.; Rud, "Veritical Integration in Meat Industry: Case of Ukraine," Manag. Theory Stud. Rural Bus. Infrastruct. Dev., vol. 38 , no. 1, pp. 88-99, 2016.

[28] A. Abdulai, "Using threshold co-integration to estimate asymmetric price transmission in the Swiss pork market," Appl. Econ., vol. 34, no. 1, pp. 679-687, 2002.

[29] S. Bojnec, "Vertical Market Integration and Competition: The Meat Sector in Slovenia," Agric. Food Sci., vol. 14, no. 1, pp. 236-249, 2005.

[30] I. C. Kubkomawa, H.I.; Adamu, S.M.; Achonwa, C.C.; Adewuyi, K.A.; Okoli, "Beef production and marketing in Nigeria: Entrepreneurship in animal agriculture," Int. J. Vet. Sci. Anim. Husb., vol. 3, no. 2, pp. $26-40,2018$.

[31] M. S. Antara, M.; Sumarniash, "Behind the Volatility of Beef Price in Indonesia," Economy, vol. 6, no. 1, pp. 1-6, 2019.

[32] F. Yustingsih, "Analisis Integrasi Pasar dan Transmisi Harga Beras Petani-Konsumen di Indonesia," Universitas Indonesia, 2012.

[33] S. Atozou, B.; Lawin, K.G.; Valea, A.B.; Aouini, "Short and Longterm Asymmetric Farm-Retail Price Transmission Analysis in the Canadian Agri-food Industry: Evidence from Dairy and Pork Sectors with Threshold Co-integration Models," J. Food Res., vol. 8, no. 2, pp 66-79, 2019.

[34] D. Diakosavvas, "How integrated are world beef markets? The case of Australian and U.S. beef markets," Agric. Econ., vol. 12, no. 1, pp. 37 53, 1995.

[35] S. Boluk, G.; Karaman, "Market power and price asymmetry in farmretail transmission in the Turkish meat market," New Medit N, vol. 4, no. 1, pp. 1-11, 2017.

[36] E. Braha, K.; Rajcaniova, M.; Qineti, A; Pokrivcak, J.; Lazorcakova, "Evidence of Spatial Price Transmission in the Case of Kosovo," Agris on-line Pap. Econ. Informatics, vol. 11, no. 1, pp. 1-12, 2019. 